\title{
Kollega Peter Andreas Munch
}

| 1880-årene malte Edvard Munch en rekke portretter av familiemedlemmer. Både faren og broren var åpenbart velvillige modeller. Av broren Peter Andreas Munch, som ble lege, finnes det åtte portretter. Fem av disse er i privat eie og er de siste årene omsatt på det private kunstmarkedet.

Engelsk oversettelse på www.tidsskriftet.no

\section{Jacob Klafstad}

jacobklafstad@tele2.no

Oslo

Erlend Hem

Tidsskriftet
Peter Andreas Munch (1.7. 1865-15.12. 1895) var det tredje av Laura (1837-68) og Christian Munchs (1817-89) barn. Paret fikk fem barn i løpet av få år, to gutter og tre jenter: Johanne Sophie (f. 1862), Edvard (f. 1863), Peter Andreas (f. 1865), Laura Cathrine (f. 1867) og Inger Marie (f. 1868).
Peter Andreas var halvannet år yngre enn Edvard (1863-1944) og beskrives som mer robust enn storebroren. Han var, som sine eldre søsken, oppkalt etter besteforeldre, men ble alltid kalt bare Andreas (1). Mens sykdom visstnok hadde ødelagt Edvards muligheter til en akademisk karriere, var

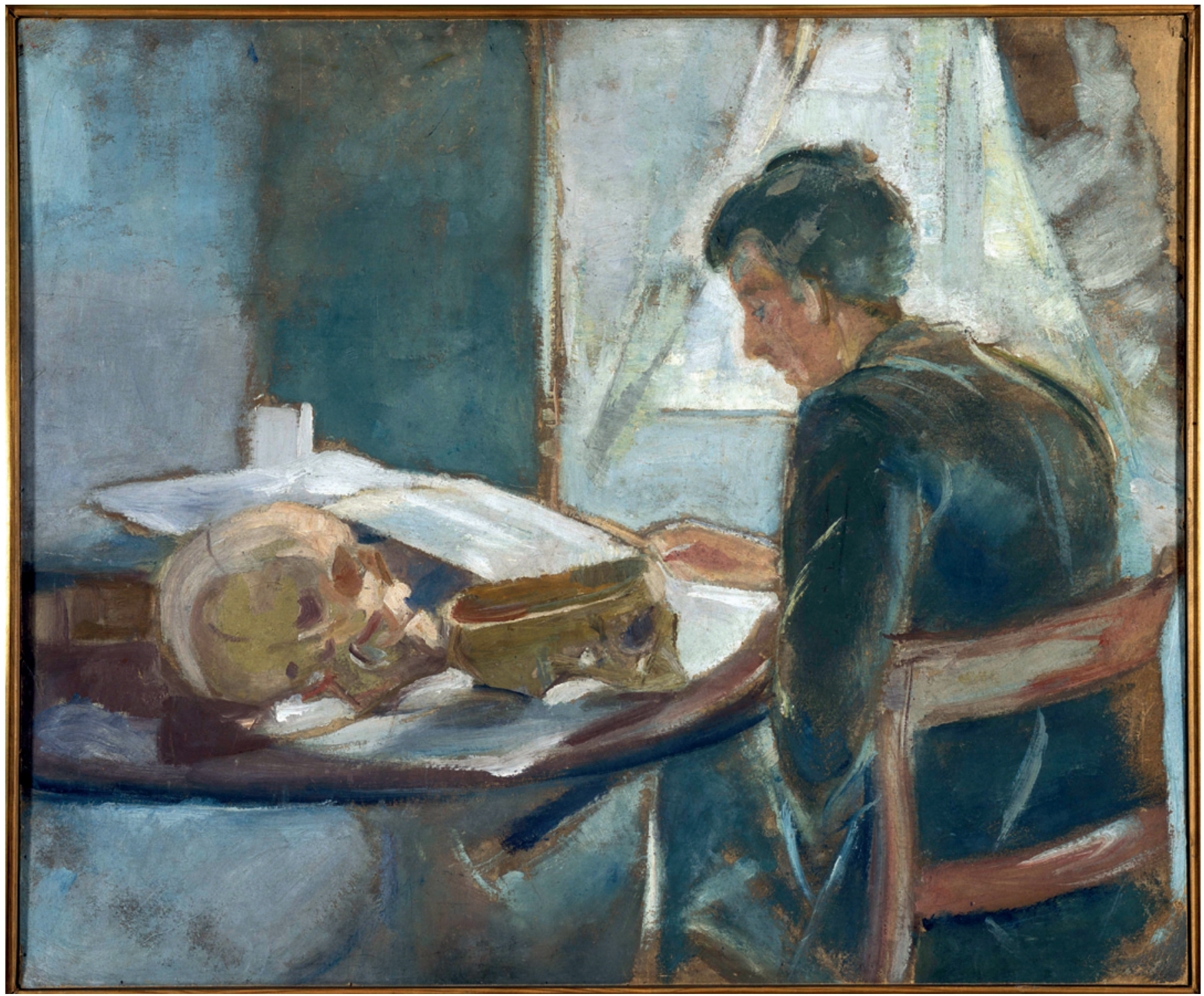

Edvard Munch: Andreas Munch studerer anatomi. 1886. Olje på ugrundert papp. $62 \times 74,5$ cm. Munch-museet MM M 202 (Woll M 134). ๑ Munch-museet/Munch-Ellingsen Gruppen / BONO 2012. Foto @ Munch-museet 
det broren som fylte den rollen i familien han fulgte i farens fotspor og studerte medisin (2). Andreas ble student i 1884, 18 år gammel, og tok medisinsk embetseksamen i 1891 (3). Forholdet mellom de to brødrene synes å ha vært godt. De delte værelse da Andreas studerte og Edvard tegnet og malte (2).

\section{Andreas' korte liv}

Andreas hadde vansker med å få seg en fast legestilling. Mest lyst hadde han til å reise langt bort, som skipslege til tropiske strøk. Han tenkte også på å emigrere (1). Men i 1894 løsnet det på flere vis. Tidlig på året forlovet han seg, 29 år gammel, med den knapt 21 år gamle Johanne Kinck (18731960), hvis far var overlærer på Lillehammer. Andreas vikarierte for en lege i småbyen, og familiehistorien forteller at Johanne Kinck kom til den unge Kristianialegen med en vond ankel, som han så på og kommenterte: «Nei, så vakre ben De har, frøken!» (1).

Egentlig hadde Andreas tenkt å prøve lykken i Amerika eller Belgisk Kongo høsten 1894, men møtet med Johannes ankel satte en stopper for det. I en periode hadde han kandidatstilling på Rikshospitalet og tjente 30 kroner måneden. Han søkte flere stillinger, uten hell, men samme høst fikk han omsider fast legestilling i Hadsel i Vesterålen. Han hadde ikke glemt sine planer om å reise ut i verden, han hadde bare forskjøvet dem til han kunne legge seg opp penger i sin anstrengende Nordlands-praksis. Han trivdes ikke den første, ensomme vinteren der oppe, betrodde han Edvard. Det var et «surt og oppslitende liv», som han ikke hadde tenkt å holde ut i mange år. Først ville han spare opp penger til bryllup og etablering, deretter komme seg til tropene for eventuelt å slå seg til der med familien (1).

Bryllupet sto i Lillehammer 19.4. 1895. Andreas ble den første og eneste av Munchsøsknene som giftet seg. Det unge paret dro til Vesterålen straks etter. De etablerte seg, Andreas' praksis gikk godt, Johanne ble gravid, men Andreas trivdes likevel ikke. Det var tanken på den forlokkende reisen sørover - nå tenkte han seg et års ferie i Sør-Amerika - som gjorde at han holdt seg der oppe (1).

Men til Sør-Amerika kom han aldri. Tidlig på vinteren ble Edvard Munchs eneste bror syk. Han utviklet lungebetennelse og døde 15.12. 1895. Han ble bare 30 år gammel, som sin mor. Johanne var sju måneder på vei. Hun ble sendt sørover, til familien på Lillehammer. I hjembyen fødte hun en datter 20.2. 1896. Denne jenta ble den eneste kjente nære slektning av Edvard Munch i neste generasjon. Andrea (1896-1980) ble oppkalt etter faren hun aldri fikk møte. Dødsfallet til denne tilsynelatende mest livsdyktige av søsknene var en dyp rystelse for hele familien. Julen 1895 ble bare trist (1). Andreas Munch er gravlagt på Krist kirkegård i Oslo $(4,5)$.

\section{«Andreas studerer anatomi»}

Bildet Andreas studerer anatomi befinner seg i Munch-museet (fig 1). Det er ingen sikre holdepunkter for datering av det. I museets arkiv er det tidfestet til 1883. Da det ble brukt som forsideillustrasjon i boken Legene og samfunnet ved Legeforeningens 100 -årsjubileum, var det denne dateringen som ble brukt (6). Imidlertid skiller det seg både i malemåte og motiv fra de mange små bildene av Andreas fra 1882/83, og man antar at det er malt noe senere. Ettersom Andreas begynte på medisinstudiet i 1885, er det nå datert til 1886 (7).

Ifølge Langaard \& Revold er dette «en skisse som i stilen viser tilknytning til Munchs eldre kolleger med deres forfinede, franskinspirerte naturalisme, men et merkelig modent arbeid, så enkelt og fast $\mathrm{i}$ komposisjonen, så fornemt i sin presise avveining av varme og kalde fargetoner» (8).

\section{Portrettene av Andreas}

Edvards Munch laget i alt åtte portretter av broren. De sju første ble trolig malt i perioden 1882/83-1886. Til det siste finnes ingen sikre holdepunkter for datering. Det er en gjentakelse et tidligere motiv, og man tror at det kan ha blitt malt til niesens 40 -årsdag i 1935, som et minne om faren (7).

Tre av de åtte portrettene av Andreas finnes i norske offentlige samlinger:
Munch-museet, Nasjonalgalleriet og Rasmus Meyers samlinger. De øvrige fem er i privat eie, og i årene 2001-07 ble de alle omsatt på det private markedet (7).

\section{Jacob Klafstad (f. 1934)}

er cand.med., cand.odont. og spesialist i kjevekirurgi. Han var ansatt som universitetslærer i Oslo og Bergen i oral kirurgi, oral røntgenologi og generell diagnostikk og i 12 år i Hærens sanitet, Sjøforsvarets sanitet og i Forsvarets sanitetsstab som overordnet administrativ militærlege.

Forfatter har fylt ut ICMJE-skjemaet og oppgir ingen oppgitte interessekonflikter.

\section{Erlend Hem (f. 1970)}

er dr.med. og assisterende redaktør i Tidsskriftet.

Forfatter har fylt ut ICMJE-skjemaet og oppgir ingen oppgitte interessekonflikter.

Litteratur

1. Næss A. Munch: en biografi. Oslo: Gyldendal, 2004: 22, 28, 147, 160-2, 170.

2. Eggum A. Edvard Munch: portretter. Utgitt i forbindelse med utstilling i Munch-museet 23. januar-3. mai 1994 i anledning av 50-årsdagen for Edvard Munchs død. Oslo: Munch-museet, Labyrinth Press, 1994: 17

3. Larsen $\emptyset$. red. Norges leger. Bd. 4. Oslo: Den norske lægeforening, 1996: 141

4. Ministerialbok, Hadsel prestegjeld, Nordland 1891 - 1903: 245. www.arkivverket.no/URN:kb read?idx_kildeid $=260 \&$ uid $=$ ny\&idx_side $=-239$ (21.12.2011).

5. Ministerialbok, Garnisonsmenigheten, Kristiania, 1894-1904: 220: www.arkivverket.no/ URN:kb_read?idx_kildeid $=4883 \&$ uid $=$ ny\&idx side $=-180(3.1 .2012)$.

6. Larsen $\emptyset$, Berg O, Hodne F. Legene og samfunnet Oslo: Seksjon for medisinsk historie, Universitetet i Oslo/Den norske lægeforening, 1986: 12-3.

7. Woll G. Edvard Munch: samlede malerier. Catalogue raisonné. Bd. 1, bd. 4. Oslo: Cappelen Damm, 2008: 96-7, 110-1, 143, 151, 1552.

8. Langaard JH, Revold R. Edvard Munch: mesterverker i Munch-museet Oslo. Oslo: Forlaget Norsk kunstreproduksjon (Stenersen), 1963: 3-4

Mottatt 23.11. 2011, første revisjon innsendt 3.1 2012, godkjent 5.1. 2012. Medisinsk redaktør Siri Lunde. 